University of Nebraska - Lincoln

DigitalCommons@University of Nebraska - Lincoln

Faculty Publications: Department of Teaching, Department of Teaching, Learning and Teacher Learning and Teacher Education

Education

January 2004

\title{
English Language Learners, Comprehensive School Reform, and State Education Agencies: An Overlooked Opportunity to Make Comprehensive School Reform Comprehensive
}

\author{
Edmund T. Hamann \\ University of Nebraska - Lincoln, ehamann2@unl.edu \\ Ivana Zuliani \\ Brown University \\ Matthew Hudak \\ Independent Researcher
}

Follow this and additional works at: https://digitalcommons.unl.edu/teachlearnfacpub

Part of the Teacher Education and Professional Development Commons

Hamann, Edmund T.; Zuliani, Ivana; and Hudak, Matthew, "English Language Learners, Comprehensive School Reform, and State Education Agencies: An Overlooked Opportunity to Make Comprehensive School Reform Comprehensive" (2004). Faculty Publications: Department of Teaching, Learning and Teacher Education. 58.

https://digitalcommons.unl.edu/teachlearnfacpub/58

This Article is brought to you for free and open access by the Department of Teaching, Learning and Teacher Education at DigitalCommons@University of Nebraska - Lincoln. It has been accepted for inclusion in Faculty Publications: Department of Teaching, Learning and Teacher Education by an authorized administrator of DigitalCommons@University of Nebraska - Lincoln. 


\title{
English Language Learners, Comprehensive School Reform, and State Education Agencies: An Overlooked Opportunity to Make Comprehensive School Reform Comprehensive
}

\author{
Edmund T. Hamann and Ivana Zuliani \\ The Education Alliance \\ Brown University \\ Matthew Hudak \\ Independent Researcher
}

\begin{abstract}
After verifying that the federally supported Comprehensive School Reform Demonstration (CSRD) program schools in the 7 states studied had a disproportionately high English Language Learner (ELL) population, we examined the understandings and guidance about ELLs that was included by those states' state education agencies (SEAs) in the policy documents that they generated for CSRD. Specifically, we looked at the CSRD plans that SEAs submitted to the U.S. Department of Education and at the first requests for proposals they circulated to schools. In those documents, we found little recognition of the dichotomy identified by Miramontes, Nadeau, and Commins (1997) between school reform efforts and accommodating linguistic diversity. We also found little evidence that SEAs were modifying CSRD to bridge this dichotomy.
\end{abstract}

\section{POLICY OVERSIGHTS AND MISMATCHES AS A SOURCE OF ELLS' STRUGGLES}

As the number of English Language Learners (ELLs) attending schools in the United States grows and as their geographic spread increases (Kindler, 2002;

Requests for reprints should be sent to Edmund T. Hamann, Education Alliance at Brown University, 222 Richmond St. Suite 300, Providence, RI 02903-4226. E-mail: Edmund_Hamann@brown.edu 
Suárez-Orozco \& Suárez-Orozco, 2001; Zehler et al., 2003), it has become even more important to identify and remedy the historic dynamics that have led to too many ELLs not thriving in school. According to the National Center for Educational Statistics, in 1995, those who had "difficulty speaking English" constituted $5.3 \%$ of the total population of 16- to 24-year-olds, but constituted $44.3 \%$ of the status dropouts within that age group. ${ }^{1}$ Despite the legal protection for ELLs guaranteed by the 1974 Lau v. Nichols U.S. Supreme Court decision, which promised ELLs access to intelligible instruction, the statistic just provided illustrates that, in aggregate and based on school completion, the school experience of ELLs has too often been inadequate.

The relative failure of schooling for many ELLs, which no doubt has many causes (some internal to schools, some external), has occurred concurrently with the contemporary emphasis on comprehensive school reform. Yet Miramontes, Commins, and Nadeau (1997) asserted that "The typical approach to program planning for English second language learners is to relegate the decision making to special programs people and to view the needs of these students as peripheral to the total school program" (p. 69). In other words, though the academic struggle of many ELLs is self-evident, and though ELLs constitute a substantial portion of enrollment in many schools across the country, there is often an unnecessary dichotomy between schools' attempts to accommodate ELLs and their attempts at comprehensive school reform (CSR; see also Datnow, Borman, Stringfield, Rachuba, \& Castellano, 2002). Though a key element of much of the CSR movement has been the encouragement of schools" importation of "research-based," externally developed school change models (Berends, Kirby, Naftel, \& McKelvey 2001; Borman, Hewes, Overman, \& Brown, 2003; Desimone, 2002; Hatch, 2000), Stringfield, Datnow, Ross, and Snively (1998) found that none of the popular CSR models were designed specifically with ELLs in mind (see also Datnow, Borman, Stringfield, Overman, \& Castellano, 2003; Yonezawa \& Datnow, 1999).

The dichotomy noted by Miramontes et al. (1997) needs further scrutiny. The double points of departure for this study are to consider whether, well away from the classroom, there were actions and practices that (a) perpetuated the dichotomy between CSR and schooling for ELLs and (b) might be linked to the educational disadvantage frequently experienced by ELLs. In a comparative study of districts' responses to growing enrollments of immigrant students, Dentler and Hafner (1997) found that a key characteristic of districts that responded successfully to this demographic change was the expertise of those away from the classroom (e.g., curriculum coordinators, superintendents, guidance counselors) regarding effective practices with ELLs. Following Dentler and Hafner, we have here consciously "studied up" (Nader, 1972); that is, we looked at those who

${ }^{1}$ These data come from The Condition of Education 1997, Supplemental Table 4-1, accessed December 5, 2000, at http://nces.ed.gov/pubs/ce/c9704d01.html. 
oversee systems to thereby broaden the empirical information available to those who study why ELLs often struggle in school.

In this study, we decided to scrutinize how ELLs were or were not considered at the state education agency (SEA) level when SEAs first took on the task of implementing the federal Comprehensive School Reform Demonstration (CSRD) program. ${ }^{2}$ More specifically, we decided to scrutinize the policy documents generated by seven northeastern SEAs (the same SEAs noted by Lane and Gracia, this issue) as they prepared to implement CSRD, a program explicitly intended to aid struggling students and to narrow achievement gaps through a process of whole-school change.

With the bulk of CSRD funds intended to assist Title I students, and with one of every five Title I-eligible students also an ELL, Menken (2000) noted that "It is therefore important that the needs of these students be addressed through comprehensive school reform" (p. 1). Yet Michael Cohen, then U.S. Undersecretary for Elementary and Secondary Education, noted in November 2000 that states' most common violation of Title I rules was their failure to include ELLs in testing and accountability measures (Zehr, 2000).

In a process (the CSRD application process) in which schools were asked by SEAs to think deeply about their current struggles and outline a research-based strategy for how they would reform and improve themselves, schools were not asked to deeply consider ELLs. This study shows that in the plans describing their proposed CSRD implementation that were submitted to and approved by the U.S. Department of Education, SEAs paid little overt attention to ELLs. This nonattention to ELLs was problematic for at least two reasons: (a) the schools that received CSRD funding enrolled a disproportionately high number of ELLs and (b) CSR efforts have too often failed to include ELLs (Datnow et al., 2003; Datnow \& Stringfield, 2000; Gándara, 1994; Miramontes et al., 1997; Stringfield et al., 1998; Valdez, 1989; Yonezawa \& Datnow, 1999). Moreover, there is a substantial, long-established research base regarding successful school strategies for ELLs that could have been referenced and tapped but was not (e.g., Berman, Minicucci, McLaughlin, Nelson, \& Woodworth, 1995; California State Department of Education, 1981, 1986; Cummins, 1989; Lucas, Henze, \& Donato, 1990; Walquí, 2000).

Our main point is that an opportunity to remedy some CSRD oversights in reference to ELLs was largely missed when SEAs did not think of them explicitly and in depth. In missing this opportunity, SEAs were no more nor less "guilty" of failing to adequately accommodate ELLs than the long list of other educational stakeholders who have created the status quo, but they were one reason the dichotomy remained

\footnotetext{
${ }^{2}$ When the No Child Left Behind Act was passed, the name of the federal Comprehensive School Reform Demonstration program (CSRD) was changed to the Comprehensive School Reform program. To emphasize the historically contingent nature of the research presented here (all of the reviewed policy documents come from 1997 or 1998), we use the older term. We use CSR as an abbreviation for comprehensive school reform in general (i.e., more than just the federal program).
} 
unbridged. Based on the data we describe here, Gándara's (1994) complaint, voiced in the mid-1990s, still pertained at the end of the decade:

As American schools continue to diversify, the nation can no longer ignore the enormous unmet needs of LEP [limited English proficient] students, nor can it ignore the innovative responses being developed locally to meet those needs, not as a part of the reform movement, but in spite of it. (p. 64)

In carrying out our study, we were aware that the label "ELL" is hazardous in some ways because within its descriptive purview are students with a broad range of language backgrounds, school and literacy experiences, and personal and family histories. Moreover, according to differing racial, ethnic, and socioeconomic identities, the welcome accorded ELLs in schools varies (Hamann, 2003; Valdés, 2001). For example, the school readiness of a Mandarin Chinese-literate son of a Taiwanese immigrant professor and the school-site response to that student will likely differ from both the readiness of and response to, say, a Creole-speaking, little-schooled immigrant Haitian teenager. Indeed, because of the intra-group heterogeneity of ELLs, schools and districts can almost always point to the success of some of their ELL students. This can obscure the fact that many of their ELLs are not faring well. It can also unfairly suggest that the problem for those poor-performing ELLs is those students themselves, according to a logic that, if some ELLs are making it, why can't the rest?

For two reasons, however, we hold onto the ELL label. First, Title I and other programs have required disaggregation of ELL school performance data; from that data, it is clear that, whatever the intragroup diversity, in comparison to other aggregated groups, ELLs fare poorly in U.S. schools. In a national educational environment purportedly devoted to educating all students to high standards, "ELL" too frequently remains a modifier describing those students who will not reach those standards. Second, pursuant to the U.S. Supreme Court's 1974 ruling in Lau v. Nichols that found unaltered school programs discriminatory to those without full English proficiency, education systems are supposed to make explicit how they will accommodate ELLs in their schools (U.S. General Accounting Office, 2001). Given ELLs' official status as a group meriting explicit accommodation, explicit plans for whole-school change (e.g., CSRD plans) should have included explicit plans for ELLs.

\section{THE NEED, THE DICHOTOMY, AND THE UNREALIZED ROLE OF SEAS}

The research literature is full of illustrations of how schooling encountered by ELLs is often flawed and how educational outcomes for ELLs thus suffer (e.g., 
Valdés, 2001; Valenzuela, 1999). There is also a literature on ELL success stories (e.g., Pugach, 1998; Romo \& Falbo, 1996; Walquí, 2000; Wilde, Thompson, \& Herrera, 1999). But in both literatures, there is little direct comment on CSR. Wilde et al.'s (1999) study stands out as an important but modest exception. Moreover, as Datnow et al. (2003), Datnow et al. (2002), and Hamann and Lane (2004) pointed out, there is little in the CSR literature that looks at the SEA role in CSR (indeed, an important reason for assembling this issue of the Journal of Education for Students Placed at Risk is to help remedy this knowledge gap).

Because CSR and ELL responsiveness have been conceptualized as separate issues, the concerns of ELL education have often not been on the table when concerns regarding CSR have been broached, except as part of broad and nonspecific language promising responsiveness to "all" students. In Sunland County (Yonezawa \& Datnow, 1999), responses to a district-wide bilingual education consent decree conflicted directly with that district's simultaneous emphasis on CSR, but this conflict was not rapidly addressed.

As an example of the gap between CSR requirements and ELL needs, nowhere in the U.S. General Accounting Office's (2001) report on meeting the needs of ELLs is there a reference to CSR. Instead, that 2001 report is full of reviews of the conflicting studies regarding bilingual and ESL education. It notes the massive disparities in how long identified ELLs stay in special programs before being mainstreamed (where, presumably, they would encounter any extant reform effort being engaged in by the mainstream portion of the school). Education of ELLs is conceptualized as a separate and discrete task, largely apart from other school programs. Yet these ELL-serving programs often are not only "special," but marginal, too (Grey, 1991; Nieto, 2000). They, too, are in need of reform if their often inadequate outcomes are to be improved.

Menken (2000) asserted that "There is a dearth of convincing research that indicates comprehensive school reform models are effective in the education of ELLs" (p. 3). LaCelle-Peterson and Rivera (1994) argued that "It is erroneous to assume that changes that affect monolingual English students favorably will automatically do the same for English language learners" (p. 55). Despite their claims, comprehensive and ostensibly research-based reforms have been implemented that either excluded ELLs (belying claims of comprehensiveness) or included them without having a research base to prove their appropriateness for ELLs (risking that the reforms were misplaced or inappropriate).

ELL student enrollments have been growing rapidly in nearly every state across the country. According to the National Clearinghouse on Bilingual Education (NCBE; now known as the National Clearinghouse on English Language Acquisition [NCELA]), 41 states in 1996-1997 had more than 5,000 enrolled ELLs and 38 had more than 1\% ELL enrollment. By 2000-2001, 45 states plus the District of Columbia had at least 5,000 enrolled ELLs and only 4 states had less than 1\% ELL enrollment. In 31 states, ELLs made up more than 3\% of enrollment (Kindler, 
2002). NCBE estimated that there would be more than 4.1 million enrolled ELL students in U.S. schools by 1999-2000, a $104 \%$ gain since 1989, constituting about $9 \%$ of the total national $\mathrm{K}-12$ enrollment. ${ }^{3}$ In actuality, NCBE underestimated: According to a more recent report from NCELA, there were more than 4.4 million ELLs enrolled in 1999-2000 (Kindler, 2002).

Although there is ample evidence that the number of ELLs in schools has been growing and will continue to grow, there is no corresponding evidence that schools, en masse, have been serving ELLs well or that services are improving. Although the terms immigrant and Hispanic are imperfect proxies for ELL, former U.S. Undersecretary of Education Garcia (1998) noted that $66 \%$ of immigrant students drop out of school (as compared to 33\% of Hispanic students and $10 \%$ of non-Hispanic Whites).

\section{CSR Models and ELL Responsiveness}

Despite ELLs' demographically growing importance, Simmons (2000), the Director of the Annenberg Institute for School Reform at Brown University, explained that "many models started with a generic student and a generic community in mind." That is, models aim for the middle, for the "universal" student (McLeod, 1994, p. 9). Quiroz (2001) pointed out that teachers in ESL and bilingual programs "have been entirely omitted from discussions of systemic reform" (p. 168). Lucas (2000), who has a long record of working with and studying ELLs, noted that "if English Language Learners are going to benefit from reforms then they have to be involved in those reforms" (for other examples of Lucas's research on ELL issues, see Lucas, 1993, 1997; Lucas \& Wagner, 1999).

These claims and findings, however, do not mean that some models do not claim responsiveness to ELLs in their literature. The Southwest Comprehensive Center published a guide (Wilde et al., 1999) that describes 18 schools successfully implementing 13 CSRD models with ELLs. That guide also describes 10 locally developed ELL-responsive school designs. Framing their report, Wilde et al. (1999) wrote, "While a number of models have demonstrated success in raising student achievement, thus far most do not address directly the learning needs of ELL populations, although a growing number of nationally available models are placing more emphasis on this population" (p. 2). Gándara (1994) noted that model developer Henry Levin sometimes consciously targeted ELLs with his model—Accelerated Schools—with some success. Gándara (1994) and Yonezawa

\footnotetext{
${ }^{3}$ These state and national data come from a chart entitled "K-12 and LEP Enrollment Trends" that was available through the National Clearinghouse on Bilingual Education website. That information can now be found using the search terms "K-12 and LEP Enrollment Trends" on the National Clearinghouse on English Language Acquisition website: http://www.ncela.gwu.edu/. The data are spread among several tables, coded by state and nation.
} 
and Datnow (1999) both noted that another model—Success for All—has been reproduced in Spanish translation (Éxito Para Todos). Datnow et al. (2002) documented one school's claim that the Comer School Development Program model had encouraged their school to be more responsive to ELLs.

More recently, some tantalizing data have emerged that suggest some models may work favorably with ELLs (e.g., Datnow et al., 2003; Datnow et al., 2002). According to a recent report by the Northwest Regional Educational Laboratory (2004), 8 of the 26 models that they include in the CSR catalog that they maintain claimed a positive impact on ELLs. However, it is important to note that these rationales were unavailable back in 1998 when SEAs were initially sharing their CSRD plans with the U.S. Department of Education and drafting requests for proposals (RFPs) for schools. Moreover, the Datnow et al. (2003) and Datnow et al. (2002) example is from a sustained study in a single urban district, which raises the possibility that the measured effect may have been a product of alignment between school reform initiatives and district policies, rather than an effect of CSR on its own. Also, at least 2 of the 13 CSR schools in that study had dual-immersion bilingual programs. Executed well, dual-immersion has proven to be a particularly effective tool for supporting ELLs' achievement (Genesee, 1999), which raises the question of whether the alleged favorable CSR effect was actually a favorable dual-immersion effect. In another of the CSR schools in the study, ELLs were generally excluded from the CSR model's adaptations; so if that school's ELLs were part of the supposed favorable effect of CSR, then, at least in that instance, the claim would be misplaced.

According to the initial federal guidance regarding CSRD, SEAs were to ensure that each school in their jurisdiction that successfully applied for CSRD funding would comply with nine components. ${ }^{4}$ The first of the nine federally required components of the CSRD program insisted that CSRD schools use effective, research-based methods and strategies. But at that time, the vast majority of evidence assembled to demonstrate the research effectiveness of externally developed CSR models had not included ELLs (Stringfield et al., 1998; Yonezawa \& Datnow, 1999). In other words, in reviewing the school reform research, SEAs and schools were making an untested assumption when they assured themselves that the research base supporting models meant those models accommodated well the needs and inclinations of ELLs. Some might have, but the evidence that they would (and would without modification) had still largely not been assembled.

Also scarce were case histories of how models can be modified to be responsive to ELLs. Some evidence has since emerged regarding customization of CSR models for ELL responsiveness and ELL student success (e.g., Berman, Aburto, Nelson, Minicucci, \& Burkart, 2000; Datnow et al., 2003; Datnow et al., 2002; Wilde

\footnotetext{
${ }^{4}$ See the Joint Explanatory Statement of the Committee of Conference (H.R. No. 390, 105 ${ }^{\text {th }}$ Congress $1^{\text {st }}$ Session). Those excerpts can be accessed at http://www.dpi.state.wi.us/dlsea/sit/csrlegis.html.
} 
et al., 1999), but much of that scant evidence was unavailable in 1998 when SEAs were first figuring out their CSRD strategies.

It is telling that none of the New American Schools models nor the CSRD models described in the Northwest Regional Educational Laboratory's catalog of models has an origin in Migrant Education, Title VII, or any similar program created specifically to serve ELLs. ${ }^{5}$ Despite strong examples of whole schools benefiting from strategies that were specifically created to be ELL-responsive (e.g., the International High School, see Walquí, 2000), the CSR movement at the turn of the millennium was not consciously trying to scale up any of those strategies.

Fillmore and Meyer (1992) described how the federal politics of bilingual/second language education in both the 1970s and 1980s meant that much of the institutional wisdom about effective programs for ELLs was lost because of the constant reconfigurations of the ELL education support infrastructure. The closure of the Multifunctional Resource Centers in the 1990s, the end of Title VII, and the transformation of the former National Clearinghouse on Bilingual Education into the National Clearinghouse on English Language Acquisition are more recent examples of the same story. These disruptions could be one reason for the lack of scaling up of any model that originated with ELL students as its initial focus population.

In a small, unpublished 1998 survey referenced in Hamann and Lane (2004), 16 of the 17 model providers named in the federal legislation that created CSRD were asked about their willingness to work in Puerto Rico (a major recipient of CSRD funds). Ten said they lacked Spanish-language materials or were uninterested for other reasons. Although responsiveness to Puerto Rico and responsiveness to ELLs are not the same issue, both require engaging with students and parents who are not necessarily proficient in English but who do know other languages.

To be sure, some CSR- and CSRD-implementing schools have figured out ways to overcome this limitation, but this school need could have been diminished if SEAs had pressured model developers to build this capacity in the first place. Moreover, though we have come to believe that local adaptations are part of what makes CSR implementation viable in many instances (Datnow et al., 2002; Hamann \& Lane, 2004), adaptations by their nature pull the model-as-implemented away from the model-as-tested, which returns us to the original quandary regarding the research base for various models' suitability for ELLs.

As a different model-related concern, Cummins, of the University of Toronto, warned that we need to distinguish a model's "coherence effect" from its pedagog-

\footnotetext{
${ }^{5}$ The Northwest Regional Educational Laboratory's catalog of comprehensive school reform models can be viewed at http://www.nwrel.org/scpd/catalog/index.shtml. Though we have found little about this effort beyond the foundation's own literature, the National Children's Educational Reform Foundation, Inc., based in Danbury, CT, has been seeking to remedy the full exclusion of Title VII-origin programs from CSRD. Their complementary models-Think-Kids, Think-Parents are Powerful, and Think-Coach-originate in a Title VII-funded effort with ELLs in Hartford, CT.
} 
ical one (personal communication, October 2, 2001). That is, it seems possible that some ELL students could gain academically after the introduction of a model, not because the model is necessarily ELL-responsive, but because a model might offer direction to a teacher who is otherwise untrained or ill-prepared to work with ELLs. Work in the "New Latino Diaspora" (Wortham, Murillo, \& Hamann, 2001) suggested that in districts newly enrolling ELLs, there is an acute absence of teacher expertise regarding pedagogy and classroom management as they pertain to ELLs (Hamann, 2003). In such sites, coherence may represent an improvement over incoherence, even if the coherent practice is not particularly ELL-responsive. Such improvements, although welcome such as they are, are not likely to remedy achievement gaps between ELLs and other students.

As a final point regarding CSR and ELLs, it seems pertinent to remember that the first substantial burst of educational planning for ELLs was the Bilingual Education Act of 1968. That policy, like other education policies of its era, did not problematize schooling and school organization per se; rather, it calculated that ELLs needed supplemental supports like other at-risk populations targeted for compensatory education (Crawford, 1995). This was a fundamentally different diagnosis than what later emerged to support CSR (Borman, 2002; Coady et al., 2003; Desimone, 2002). The rationale for CSR was grounded by the assertion that the structure of school itself was fundamentally flawed and that restructuring was necessary if all students' needs were to be met (Sizer, 1984). A careless combination of these diagnoses could rationalize excluding ELLs as a target constituency of CSR under a logic that their needs can be accommodated without CSR.

\section{Problematizing the SEA Role}

The central task of this article is not to ask whether ELL students were being served adequately by "special" programs in the seven states studied, per se, or even whether they were being served well at the original 196 CSRD schools within these states. Rather, we ask whether the needs and capabilities of ELLs were part of the CSR conversations in those states and, more specifically, whether they figured significantly in those states' initial CSRD planning back in 1998.

There are many important questions to ask regarding school reform and responsiveness to ELLs, but our inquiry builds from Dentler and Hafner's (1997) finding that improved and sustained ELL achievement requires not just adequate awareness of ELL concerns at the classroom level, but also an awareness of and responsiveness to ELL concerns in tiers at some remove from the classroom. Dentler and Hafner's (1997) analysis found school and district administrators' understandings of ELLs' needs and circumstances to be correlated with ELLs' academic achievement- the better their understanding, the higher ELL students' achievement. Griego-Jones (1995) made a similar point, noting that effective responsiveness to newcomer students requires systemwide buy-in to proposed learner-responsive 
adaptations. We are extending their findings to include the SEA level because Yonezawa and Datnow's (1999) work and Beck and Allexsaht-Snider's (2001) research detailed how an SEA can impede district- and school-level responsiveness to CSR and ELLs, respectively. Also, Fink (2000) noted that innovative schools operating in larger traditional policy climates (i.e., with static and hierarchical district and SEA management) ultimately lose their innovativeness, returning to a traditional equilibrium. Because the traditional school equilibrium for ELLs typically translates into ELLs' disadvantage, it follows that in the absence of new thinking and new structures at the SEA level, in this case new ELL-responsive structures tied to CSRD, one can expect the diminution of any improved responsiveness to ELLs that might have been created at the classroom and CSRD-school levels. School and district responsiveness to ELLs is not easily sustained without SEA-level understanding and support.

Such understanding and support can be created if and when SEAs learn from school and district successes or from their own staff who are involved with Migrant Education or Bilingual/ESL/ESOL programs. If this was happening in 1998, there should have been recoverable evidence of mechanisms for such learning (e.g., CSRD RFPs that give evidence of consultation with SEA officials concerned with Title VII and Migrant Education). There should also be evidence of lateral communication.

Lusi (1997) noted that most SEAs are traditionally structured with multiple and fixed layers of hierarchy and vertical lines of communication. She endorsed the idea that SEAs become learning organizations, but explained that SEAs' typical organizational structures inhibit organizational learning and change. It follows that if those portions of SEAs concerned with CSRD needed to learn new habits to better accommodate ELLs but were not well-positioned for such learning, then the organizational status quo would persist, with CSRD making little accommodation for ELLs.

It may at first seem odd or even unfair to focus on SEAs when describing inadequacies of CSRD vis-à-vis ELLs because the program has a federal and not a state origin and because the models that overlook ELLs (or that have not been proven effective with ELLs) are also outside SEAs' specific purview. But there are a few key SEA roles in CSRD worth remembering. First, as authors of the RFPs read and responded to applicant schools, SEAs helped set the initial tone for how schools in their states would respond to CSRD and how schools would understand what they were expected to do. Second, as Maine has amply demonstrated (Hamann \& Lane, 2004; Hamann, Lane, \& Hudak, 2000), and as Datnow (this issue) and Lane and Gracia (this issue) also illustrate, SEAs have had wide scope to add requirements and shape implementation of CSRD within their states. Third, as the coordinators of the grant solicitation and grant review processes, and as the ultimate authorities regarding what school reform models would or would not be implemented in their CSRD schools, states have had important decision-making power in relation to the world of model providers. That is to say, SEAs were positioned in the CSRD process to 
strongly influence the market for CSRD models, influencing which schools could buy models and which models were available to be bought. Model providers respond to market forces, but SEAs created no market demand for models that originated in programs for ELLs or that explicitly responded to them. No demand, little supply.

\section{METHOD}

In the absence of any participant observations, this study is not a conventional ethnography. However, it is very much an anthropological text, centrally concerned with the production, communication, and contestation of meaning (Levinson \& Sutton, 2001). As Shore and Wright (1997) explained in their call for an anthropology of policy

Policies are inherently and unequivocally anthropological phenomena. They can be read ... as classificatory devices with various meanings, as narratives that serve to justify or condemn the present, or as rhetorical devices and discursive formations that function to empower some people and silence others. (p. 7)

In this case, the imagined needs of ELLs, the sensibilities regarding within whose purview ELLs fell, and the counterpart understandings regarding what CSRD was, what it was to do, and who it was for are all salient. The examined policy documents illustrate these perhaps subconscious understandings.

Nader (1972) asserted that in anthropology, the research question should direct methodology rather than vice versa. The research question pursued here concerns SEAs' roles in identifying and rectifying (or not) the dichotomy between CSR and ELL responsiveness. That topic is potentially as much about what did not occur, what was not thought about, as about what did occur, so there was no key moment to witness. It was documentary evidence that could shed light on the issue. So the methodologies pursued here echo the "studying culture at a distance" strategies pioneered by Ruth Benedict, Margaret Mead, and other anthropology luminaries back in the 1940s as part of the Research in Contemporary Cultures center (Beeman, 2004; Mead \& Metraux, 1953).

Following Shore and Wright (1997), who emphasized that an anthropology of policy should gather new forms of data, notably "policy documents" (p. 15), the data for this study were all generated by a document review. Patton (1990) noted that documents can reveal information to which a researcher would not otherwise be privy. Furthermore, there is a precedent for reviewing policy documents to study ELL education issues. In a study published by the Center for Equity and Excellence in Education, Rivera, Stansfield, Scialdone, and Sharkey (2000) relied almost entirely on policy documents for their analysis of state policies for the inclusion and accommodation of ELLs in state assessment programs. 
With the goal of understanding how ELLs were thought of and responded to at the SEA level during the original roll-out of CSRD, we manually chronicled and examined every reference to "Limited English Proficiency" (LEP), "English Language Learner" (ELL), "English as a Second Language" (ESL), "English for Speakers of Other Languages" (ESOL), "language minority," "Spanish-speaking students," "Hispanic students," "bilingual education," "Teaching English to Speakers of Other Languages" (TESOL), "Title VII," and "non-English-proficient" in seven states' CSRD applications and RFPs. ${ }^{6}$ Because the initial impetus for CSRD was federal, we also looked for ELL references in the federal guidance to states.

In our examination of each reference, we categorized each one as referring to ELLs "concretely" or "peripherally" and considered whether the reference promised or promoted practices that, according to research, help ELLs succeed. For our purposes, a concrete reference was a reference that required new and overt attention to ELLs. In contrast, we defined as peripheral a reference that lumped ELLs into a larger and vaguely defined group (e.g., as a type of at-risk student), that only repeated existing federal requirements (e.g., that data on ELLs be collected), or that repeated verbatim federal language (e.g., Component 2 of the nine original federally defined CSRD components, which specified "children with limited English proficiency" as one of three groups of students that need to be included in a plan for "all" students).

Noting that most CSRD model providers did not initially target ELLs in their model design, we designed our study to see whether SEAs had recognized this oversight and attended to it within their state CSRD funding proposals and RFPs. Because each state was required to have their CSRD implementation plan approved by the U.S. Department of Education as an early step in the roll-out of CSRD, we decided that those proposals were a good place to look for overt consideration of ELLs. With U.S. Department of Education approval in hand, states then distributed RFPs to schools and districts. Because those RFPs were central formal communiqués to schools of SEAs' expectations and understandings regarding CSRD, those RFPs were also important sources of data.

These two texts (per state) were artifacts of policymaking conversations, providing a partial record of what was considered and a specific record of the ideas that were approved. We acknowledge that there are limitations to only using text sources as data. Nonetheless, we persist with this methodology for two complementary reasons. We wanted to preserve in our research design as much as possible

\footnotetext{
${ }^{6}$ Some of these terms, notably Hispanic, are not necessarily references to English Language Learners (ELLs). Others (e.g., limited English proficient) have been criticized because they identify learners by what they do not know. For this review, however, the goal was to be thorough and to catch all possible references to ELLs, however oblique or problematic. As per the federal Lau Remedies, we are using ELL here specifically to refer to those students whose progress learning English (including oral fluency and literacy) is not yet sufficient to avoid interfering with their learning in an unsupported classroom environment. By federal law, schools, districts, and states are supposed to identify all ELLs and ensure their access to appropriately modified instruction.
} 
the perspective schools would have had with just the formal guidance of an RFP. Collecting other forms of data would move us away from that. Second, we wanted to avoid directly impugning any specific individual. By not collecting any information on what various CSRD-affiliated SEA officials knew or did not know about ELL responsiveness, we have avoided passing judgment on their professional knowledge. Instead, we focus only on whether knowledge related to ELL responsiveness was presumed relevant and made formally manifest.

Our selection of states for this study reflects two logics. Most important, we adhered to the logic of maximum variation sampling (Patton, 1990). We wanted a sample that included high- and low-impact jurisdictions and big and little SEAs. If the document record of a highly impacted state looked like that of a state with a very small ELL enrollment, that could bolster a claim that the consideration of ELLs was not originally on SEAs' radar. Although we did not use a fixed, single definition of high impact, we did note that New York had the fourth highest ELL enrollment in the country. By proportion of ELL enrollment, Rhode Island and Massachusetts also ranked in the top half of states (18th and 22nd, respectively).

As a different rationale for our site selection, within the jurisdictions of the states studied were the schools, school districts, SEAs, and universities to which 166 of the 1,064 Fiscal Year 1999 Title VII allocations were directed (15.6\%), though those jurisdictions together hosted only $7.7 \%$ of ELLs nationwide. ${ }^{7}$ Title VII was a primary funding vehicle for special programs to serve ELLs, so Title VII allocations hint at the presence of ELLs in schools, the presence of professionals seeking extra resources for them, and the existence of regionally available expertise regarding ELL-responsive education. If ELLs are going to be included in educational policy anywhere, it seems more likely that they would draw attention in jurisdictions with an abundance of Title VII grants.

We also selected our sample for logistical reasons. Our employer had a contract to support applied educational research and technical assistance in all seven of the included states. Raising a point that we return to in the conclusion, it made sense for us to scrutinize the roll-out of CSRD in our local region, particularly because we received a supplementary federal allocation in 1998 to support and study CSRD implementation. Thus this study also gave us a chance to consider the needs of our region and scrutinize our own efforts on behalf of CSRD implementation.

Our study includes seven states, four with substantial urban ELL populations (New York, Connecticut, Massachusetts, and Rhode Island) and three with decidedly smaller but quickly growing ELL populations (Vermont, New Hampshire,

\footnotetext{
${ }^{7}$ These Title VII Fiscal Year 1999 data were found on the old National Clearinghouse on Bilingual Education website, but it can now be accessed at http://www.ncela.gwu.edu/oela/obemla/grants/fy1999/. The data show that Connecticut received 11 Title VII grants, Maine 11, Massachusetts 29, New Hampshire 6, New York 101, Rhode Island 5, and Vermont 3. The portion of all ELLs living within the studied region was derived from the data presented in Table 1.
} 
and Maine). Vermont, which in 1998-1999 counted only 894 ELLs, subsequently began developing ELL-sensitive performance-based assessment instruments and strategies. In another of the low-ELL states in our sample, Wortham (2001) documented the contradictory and ultimately inadequate responsiveness of a high school to its growing ELL population. That school, near a food processing plant that has attracted Mexican and Mexican-descent workers, became a CSRD school.

In contrast to the novelty and generally small scale of ELL enrollments in the northern New England portion of our sample, our regional review also includes New York, which for more than a century has practically been defined by being a globally significant locus of immigration. New York City is home to the International High School, exemplary for its ELL responsiveness (Walquí, 2000) and to other explicitly ELL-responsive schools. Upstate New York is the most important area within our sample for accommodating families (often Spanish-speaking) involved in migrant agricultural work (although Maine and Connecticut also host substantial migrant agricultural workforces). Small and large regional cities within our sample—-for example, Bridgeport, CT; Willimantic, CT; Hartford, CT; Central Falls, RI; Providence, RI; Holyoke, MA; Lowell, MA; Lawrence, MA; Boston, MA; Nashua, NH; Portland, ME; Lewiston, ME; Rochester, NY; and Buffalo, $\mathrm{NY}$-host sizeable ELL populations because of refugee resettlement or economic niches attractive and accessible to those not proficient in English. Despite being concentrated in one corner of the country, our sample is heterogeneous and includes ELLs whose families came to the region for reasons similar to those occurring elsewhere in the country.

As a crucial final methodological point, there is a historic dimension to our study. Though CSRD is a relatively new program (first funded in 1998), our primary text data are all from 1998 and, as such, it is a reliable source of circa-1998 thinking and planning. But it is not necessarily a reliable indicator of more recent SEA perspectives and actions. In the case of New York, the 1998 documentation is clearly dated because newer statewide CSRD evaluations have compelled attention to ELLs that the original planning material (e.g., the RFP) did not. Our point is to emphasize what did not happen; we are not making claims regarding what is or is not currently occurring. Indeed, as Lane and Gracia's article (this issue) maintains, these seven SEAs have been eager and perhaps even exemplary in refining and improving their coordination and oversight of CSRD since 1998. Nothing offered here counters that representation.

\section{REVIEWING THE DATA}

Northeastern SEAs did direct CSRD funds to schools with proportionally high ELL enrollments. As Table 1 makes clear, CSRD schools in the region studied en- 
rolled a large and disproportionate number of ELL students (compare percentages in Table 1). ELL enrollments at the first CSRD schools in the region averaged $12.7 \%$, in comparison to 5.4\% ELL enrollment in all of the region's schools. Although the 123,612 students enrolled at CSRD schools in the seven states represented $2.5 \%$ of total $\mathrm{K}-12$ public enrollment in the region (i.e., about 1 in 40 students in the region attended a CSRD school), the 15,719 ELL students in the region's CSRD schools represented 5.7\% of the total identified ELL student population (i.e., about 1 of every 17 ELL students in the region was at a CSRD school).

While assembling the data for Table 1, we found that 24 CSRD schools in New York, Connecticut, Massachusetts, and Rhode Island had ELL enrollments exceeding $25 \%$ and 4 exceeded $40 \%$. Vermont had two CSRD schools with more than $18 \%$ ELL enrollment. At these schools at least, ELL responsiveness would appear to be a central school priority, and starting a conversation about whole-school reform with the question "what do ELL students need?" would not

TABLE 1

English Language Leaner (ELL) Enrollment in Seven States' Comprehensive School Reform Demonstration (CSRD) Schools

\begin{tabular}{|c|c|c|c|c|c|c|c|}
\hline \multirow[b]{3}{*}{ State $^{a}$} & \multirow{2}{*}{\multicolumn{2}{|c|}{$\begin{array}{c}\text { Statewide ELL } \\
\text { Enrollment in } \\
\text { 1998-1999 }\end{array}$}} & \multirow{3}{*}{$\begin{array}{l}\text { Statewide Total } \\
K-12 \text { Enrollment }\end{array}$} & \multicolumn{4}{|c|}{ Enrollment at CSRD Schools } \\
\hline & & & & \multicolumn{2}{|c|}{ ELLs } & \multicolumn{2}{|c|}{ Total } \\
\hline & $N$ & $\%$ & & $N$ & $\%$ & $N$ & $\%$ \\
\hline Connecticut (25) & 19,811 & 3.6 & 544,657 & 1,534 & 11.3 & 13,638 & 2.5 \\
\hline Maine (11) & 2,518 & 1.2 & 212,986 & 59 & 0.9 & 6,608 & 3.1 \\
\hline Massachusetts (52) & 45,325 & 4.7 & 964,000 & 3,401 & $13.8^{\mathrm{c}}$ & 24,716 & $2.6^{\mathrm{c}}$ \\
\hline New Hampshire (6) & 2,089 & 1.0 & 206,783 & 3 & 0.1 & 2,417 & 1.2 \\
\hline New York (86) & 195,320 & 6.8 & $2,852,000$ & 9,884 & 14.3 & 69,331 & 2.4 \\
\hline Rhode Island (7) & 7,739 & 5.0 & 154,785 & 713 & 16.7 & 4,275 & 2.8 \\
\hline Vermont (9) & 894 & 0.9 & 105,106 & 125 & 4.8 & 2,627 & 2.5 \\
\hline Regional totals (196) & 273,696 & 5.4 & $5,040,317$ & 15,719 & $12.7^{\mathrm{c}}$ & 123,612 & $2.5^{\mathrm{c}}$ \\
\hline National totals & $3,540,673$ & $7.7^{\mathrm{c}}$ & $46,153,266$ & \multicolumn{2}{|c|}{ Not calculated } & \multicolumn{2}{|c|}{ Not calculated } \\
\hline
\end{tabular}

Note. The data assembled in Table 1 come from myriad sources. Most enrollment data are from 1998-1999, with the exceptions of New Hampshire, and, in part, Maine, which include 1999-2000 figures. A full description of the sources for these data can be found in Hamann, Zuliani, and Hudak (2001).

aNumber of CSRD Schools as of September 2000 are given in parentheses.

${ }^{b} E L L$ data from the Grafton Street School in Massachusetts were unavailable, so both the Massachusetts and Regional CSRD totals are undercounts by one school.

${ }^{\mathrm{c}}$ These national figures come from a chart created by the National Clearinghouse on English Language Acquisition that claims the number of ELLs in the United States jumped from 3.5 million to 4.4. million between 1998-1999 and 1999-2000. This leap is likely the result of much more careful counting rather than a surge of 900,000 students. Noting this helps explain the apparent discrepancy between the figures in Table 1 and those cited earlier regarding national ELL enrollment. 
be inappropriate. Exceptionally, Maine's ELL enrollment at its CSRD schools was slightly below the state average, and New Hampshire's six CSRD schools enrolled just 3 of the 2,089 identified ELL students in that state. ${ }^{8}$ For New Hampshire, it seems pertinent to ask how and why initial CSRD resources largely bypassed ELLs. For Maine, ELLs were underrepresented in CSRD because there were fewer ELL students at the high school level (where all of its CSRD resources are concentrated) and no schools were funded in Portland or Lewiston, which host most of the state's ELLs.

\section{The Documentary Evidence}

Before looking directly at SEA applications and RFPs, it is instructive to consider the three-page agenda for the February 18, 2000 U.S. Department of Education-sponsored meeting for SEA CSRD staff from all over the country. That meeting, A Workshop for State Education Agency Staff on FY2000 Comprehensive School Reform Demonstration Program Awards, had two references to ELLs on the formal agenda. The first was a question. The last of nine bulleted topic questions for "Breakout Session 1" asked, "How can schools be assisted to prepare school reform plans that address the needs of all students in the school, including students with disabilities and English Language Learners?" The other reference also paired ELLs and students with disabilities. After the five main bullets for "Breakout Session 2" was a heading entitled "Other key issues for discussion." Under that heading were nine more subbullets, the eighth of which read, "Addressing the needs of students with disabilities and English Language Learners." Using the same peripheral/concrete classificatory system that we apply shortly to the SEA policy documents, both of these references would count as peripheral.

The references in that meeting agenda are like most of those we found in the state plans. Like the state plans, the references were few and tended to list ELLs with other groups with whom their only commonality was that the other groups also "don't fit" with the standard operational norms and procedures of schooling (Deschenes, Cuban, \& Tyack, 2001). As in the state plans, consideration of ELLs in the meeting agenda seemed to be a secondary or tertiary concern. This suggests that how to do reform and who it is for were separate concerns, with the first meriting the lion's share of attention.

A caveat should be noted prior to reviewing the main data set: When we realized that both New York and Massachusetts appeared to have paid scant attention to ELLs (although they had the greatest numbers of ELLs out of the seven states studied), we looked at newer materials from both states to see if we could identify alternative proof of CSRD responsiveness to ELLs. Clearly, New York quickly became more ELL-responsive. Looking at their initial CSRD state evaluation plan (co-pro-

\footnotetext{
${ }^{8}$ These data are based on 1999-2000 school-year enrollment information, which can be found at http://www.measuredprogress.org/nhprofile/SchEnroll.cfm.
} 
duced with the University of the State of New York), we found a much richer source of ELL references. Because of Massachusetts' comparatively high ELL enrollment, we also considered that state's continuation of CSRD funding application. This document did reference ELLs, but did not substantively change the original RFP's modest emphasis regarding ELLs.

Looking at the ELL references in the seven states' original CSRD plans and those states' first round of RFPs to schools, the majority of references were peripheral references, often including ELLs in lists of "special populations." Several states (Massachusetts, New Hampshire, and New York) made reference to the Title I rules from the 1994 Improving America's Schools Act that required disaggregation of ELL student achievement data. Rhode Island makes reference to its database on schools and students, called Information Works!, which also disaggregates ELL achievement, perhaps in an effort to comply with Title I. Although such inclusions illustrate an awareness of federal requirements, without further development, they promise only procedural compliance rather than active investigation and resolution of problems that ELLs encounter, as evidenced by achievement results and dropout statistics. Moreover, listing the federal requirements without further comment leaves unclear whether SEAs are aware of and actively willing to respond to the special challenges of fair assessment of ELLs (Menken, 2000). There is a wealth of literature about the hazards of using inappropriate assessment instruments with ELLs and also about why excluding ELLs from standardized assessments is problematic (because it enables schools to be less accountable for ELLs' achievement than other students'). ${ }^{9}$

Of the ELL references we found, many were in the CSRD "Continuum of Evidence of Effectiveness" charts and in lists of the nine components of CSRD programs (specifically the reference in passing in federal Component 2).$^{10}$ Both of these sources were provided to the states by the U.S. Department of Education and were simply inserted in the state applications. There were few ELL references in categories where such references were not already required by federal guidelines.

In none of the applications was an entire paragraph devoted to ELL students. Despite federal Component 9 for CSRD requiring explicit identification of how CSRD funds would be aligned with other federally funded programs at a school, none of the state applications and RFPs included references to the types of programs (ESL, ESOL, Bilingual, Title VII, or Migrant Education) that, at that time,

\footnotetext{
${ }^{9}$ Regarding assessment and ELLs see, for example, Durán (1989), Genesee and Upshur (1996), Gómez (1998), Hamayan (1995), Hamayan and Damico (1991), Lachat (1999), Lachat and Spruce (1998), McLeod (1994), O’Malley and Valdez-Pierce (1996), and Saville-Troike (1991).

${ }^{10}$ The original Obey-Porter CSRD-authorizing legislation included no references to ELLs. However, as one of the few modifications to the legislation's terminology, a reference to ELLs was added to Component 2 in the U.S. Department of Education's nonregulatory guidance to states.
} 
were the most common school programs for ELLs. Nor did we encounter any references to the federal emergency immigrant education fund, which also has particular pertinence to the education of ELLs.

Perhaps Rhode Island's and Massachusetts' RFPs could have compelled schools to reference such programs as part of a response. New York's later, more concrete, expectations for schools in its state CSRD evaluation protocol might also have compelled schools to include these programs in their overall consideration of reform, but such expectations postdated that state's initial CSRD policymaking (as captured in the state application and RFP) and thus presumably also postdated schools' initial CSRD decision making.

Before sharing the 32 references to ELLs that we did find (an average of 4.6 per state and 2.3 per document), we should emphasize that these references were scattered among hundreds of pages we reviewed. Because they are all listed later, they may inadvertently appear abundant; however, we estimate that there was only one reference per every 20 pages.

Rhode Island's application (see Table 2) and its school and district RFPs dealt with ELL accommodation a little more concretely than other states and the references in its documents seem more deliberate. Whereas the other states only mentioned that the data should be disaggregated in terms of language minority, for example, Rhode Island also explicitly identified ELLs as a target population for whom the equity gap needed to be eliminated. In this case, the goal was for equitable achievement outcomes as measured on state-mandated standardized tests, which, although an example of conscious inclusion, neither referenced nor resolved the hazards of using standard assessments with ELLs (Menken, 2000; Solano-Flores \& Trumbull, 2003).

Massachusetts (see Table 3) awarded points for applications that indicated ELL responsiveness, but the rubric category in which those points were awarded asked for 11 different categories of information with several of those categories including multiple components. In other words, a "good" or even "exemplary" answer could avoid specifying much about ELLs beyond a bland phrase ensuring ELLs' inclusion. Massachusetts' initial CSRD roll-out was not silent regarding ELLs, but neither was it sufficiently detailed to ensure that schools explicitly considered and reconciled their plans for ELLs and for CSRD.

Like New York, Massachusetts also specifically referred to ELLs in its follow-up communications with schools, but in this instance, the reference showed more of a continuity of real, but modest, responsiveness to ELLs, not a growing focus. Item 2 in their continuation grant application asked: "Describe the components of your CSRD program that were addressed during Year 1 based on your Comprehensive Needs Assessment. How do these components fit together to form a comprehensive design focused on success of all students, including students with disabilities and English Language Learners, in meeting the Massachusetts learning and performance standards?" This request is consistent with earlier understandings and instructions contained in Massachusetts' application and RFP. There, too, 
TABLE 2

Rhode Island

Section and
Page Number Description $\quad$ Peripheral Concrete

State APP P. 2, Reference to LEP in introduction as part of the line 8 description of diverse student groups in Rhode Island public schools.

State APP P. 17, Reference to English proficiency. Mentioned in section line 5 describing how Rhode Island intends to assess performance in terms of making reductions in equity gaps between diverse groups of students. English proficiency students is listed as one these groups.

State APP P. 18, Reference to LEP in response to Application line 4 Requirement 4 . The state's school information database, Information Works, addresses the disaggregation of information for the targeted groups served by CSRD: Limited English proficiency is listed as one such target group.

State RFP, P.10, Reference to children with LEP in the requirements of line 2 from DISTRICT NARRATIVE Question 4. This group is bottom part of a list of student groups that should be included in a clear district plan for measuring achievement.

State RFP P. 12 Reference to children with LEP in scoring key for Question 4. Explicitly planning for disaggregation of ELL assessment is part of a "strong" answer.

State RFP, P. 18, Reference to children with LEP in SCHOOL lines 8 and 22 NARRATIVE Question 4 and in the requirements for this question. This group is part of a list of student groups that should be enabled by the CSRD model to meet Rhode Island performance assessments.

State RFP, Scoring Reference to LEP in the requirements of DISTRICT Guide, P. 8 NARRATIVE Question 4. This group is part of a list of student groups that should be included in a clear district plan for measuring achievement.

State RFP, Scoring Reference to LEP in scoring key for DISTRICT

Guide, P. 9 NARRATIVE Question 4.

State RFP, Scoring Reference to children with LEP in SCHOOL

Guide, P. 16 NARRATIVE Question 4 and in the requirements.

State Evaluation Reference to English proficiency. Mentioned in section Application describing how Rhode Island intends to assess Requirement 4, performance in terms of making reductions in equity P. 17, line 11 gaps between diverse groups of students. Limited English proficiency students are listed as one these groups.

Note. $\quad$ APP = Application; LEP = limited English proficiency; RFP = Request for Proposals; $\mathrm{CSRD}=$ Comprehensive School Reform Demonstration. 
TABLE 3

Massachusetts

\begin{tabular}{|c|c|c|c|}
\hline Section and Page Number & Description & Peripheral & Concrete \\
\hline $\begin{array}{l}\text { State Application, Attachment } \\
\text { B-Scoring rubric, p. } 18 \text {, line } 2\end{array}$ & $\begin{array}{l}\text { Reference to ELLs along with Title I } \\
\text { students and special education students } \\
\text { as population that improvement } \\
\text { strategy needs to target. }\end{array}$ & & \\
\hline $\begin{array}{l}\text { State Application, Appendix B- } \\
\text { Federal continuum of evidence, } \\
\text { line } 6 \text { from bottom }\end{array}$ & $\begin{array}{l}\text { Reference to match between language } \\
\text { minority composition at schools where } \\
\text { model has worked and applicant school. }\end{array}$ & & \\
\hline $\begin{array}{l}\text { State Application, Appendix C- } \\
\text { Suggestions for LEA Evaluation } \\
\text { of CSRD, line 7,3rd paragraph (a } \\
\text { photocopy of this page is included } \\
\text { as appendix D in the state RFP) }\end{array}$ & $\begin{array}{l}\text { Reference to English proficiency } \\
\text { status. Mentioned as a Title I category } \\
\text { for which the assessment of student } \\
\text { performance results should be } \\
\text { disaggregated. }\end{array}$ & & \\
\hline State RFP p. 6, line 2 & $\begin{array}{l}\text { Reference to ELLs in list of information } \\
\text { to be provided by the schools seeking } \\
\text { funds. Mentioned in Item } 4 \text {, } \\
\text { "Description of Proposed Programs," as } \\
\text { a type of at-risk population. }\end{array}$ & & \\
\hline $\begin{array}{l}\text { State RFP, Scoring rubric for } \\
\text { school application narrative, } \\
\text { line } 14\end{array}$ & $\begin{array}{l}\text { Reference to ELLs as part of Item } 4 \\
\text { "Description of proposed program": } \\
\text { "Indicates how the program will focus } \\
\text { on improving teaching and learning and } \\
\text { how it will assist all students (including } \\
\text { Title I, special education, and English } \\
\text { language learners)." }\end{array}$ & & \\
\hline $\begin{array}{l}\text { State RFP, Chart of } 9 \text { CSRD } \\
\text { components, line } 3\end{array}$ & $\begin{array}{l}\text { Reference to ELLs. Mentioned in Item } \\
2 \text {, "Comprehensive design with } \\
\text { aligned components," of CSRD chart } \\
\text { to be sent in with school application. }\end{array}$ & & \\
\hline
\end{tabular}

Note. $\mathrm{CSRD}=$ Comprehensive School Reform Demonstration; ELL $=$ English Language Learner; LEA = local education agency; RFP = Request for Proposals.

schools were asked to detail their programs' responsiveness to ELLs, but only in the context of explaining their responsiveness to several special populations and with just minor consequence if their answer was bland and brief.

Connecticut (see Table 4) addressed ELLs' situation through CSRD only in insistent but vague assertions that the reform process must serve all students. At the beginning of Connecticut's application, the intent was announced for Connecticut's CSRD implementation to align with its Nurturing the Genius of Connecticut's Students: Connecticut's Comprehensive Plan for Education 1996-2000 (Connecticut State Department of Education, 1997). That plan, as described on the sixth page of Connecticut's CSRD application, identified "quality and diversity" as one of "four 
TABLE 4

Connecticut

\begin{tabular}{lll}
\hline Section and Page Number & Description & Peripheral Concrete \\
\hline
\end{tabular}

State APP P. 8, Line 11

State APP P. 12, line 2 from bottom

State RFP P. 11, line 8 from bottom

State RFP P. 40

State RFP P .43, line 12 from bottom

State RFP P. 44, line 8 in 3rd paragraph

State RFP P. 52, Response to question A-2
Reference to children with limited English proficiency in Item 2, "Comprehensive design with aligned components," in list of 9 components of CSRD programs.

Reference to bilingual and ESL coordinator monthly meeting as part of Connecticut "Dissemination Strategies."

Reference to children with limited English proficiency in Item 2, "Comprehensive design with aligned components," in list of 9 components of CSRD programs.

Reference to children with limited English proficiency in Item 2, "Comprehensive design with aligned components," in list of 9 components of CSRD programs.

Reference to language minority composition with respect to student demographics in "Continuum of Evidence of Effectiveness" chart as part of implementation item.

Reference to "Spanish speaking community" in Example 2 of how the "Continuum of Evidence of Effectiveness" might be used.

Reference to "children with limited English proficiency" as example of children that will be enabled to reach challenging academic standards through the coordination of comprehensive education improvement strategies.

Note. $\mathrm{APP}=$ Application RFP $=$ Request for Proposals.

strategic priorities," while making no specific reference to ELLs. The plan was then described as intending to meet five long-term educational priorities, four of which include the word "all" (i.e., "All Students," "All Learners," "All Students" [again], and "All Citizens"). Clearly Connecticut's goal, at least as is ascertainable from the written text, was not to exclude, but there was little specific guidance about how to include ELLs. Again, none of the oversights noted earlier - the absence of research on CSR models and ELLs, the challenges of ELL assessment, the inattention to the research on what worked for ELLs-were specifically addressed.

Except for a century-plus history of steady, if modest, immigration from French-speaking Quebec, northern New England historically has not hosted many ELLs. At the time CSRD was launched, this region had a lower proportional ELL 
presence than most of the United States. Thus, it is not surprising that Maine's, New Hampshire's, and Vermont's applications contained few references to ELLs (although Vermont's two highest proportion ELL schools—both over 18\%-both became CSRD schools).

Because Maine (see Table 5) received a waiver from the U.S. Department of Education to concentrate its modest CSRD allocation entirely at the secondary level in support of a state-sponsored secondary school reform, a waiver that included exemption from formally tying CSRD to Title I (because Title I is concentrated at the primary level), Maine unwittingly removed a number of ELL students from being recipients of CSRD support. (It follows that there are more ELL students at the primary level, because elementary school students have had fewer years of schooling to learn English; ELLs at the secondary level are predominantly newcomers.) We have written favorably elsewhere (Hamann \& Lane, 2004) of the ambition and promise of Maine's CSRD program; however, in reference to the key concern of this report, that ambition and promise were not substantially directed toward ELLs. As an appendix to its application, Maine attached the Northwest Regional Educational Laboratories catalog of school reform models. That catalog includes several ELL references that are not repeated in Table 5.

New Hampshire (see Table 6) had one potentially concrete reference to ELLs. With content exactly matching that used by Massachusetts in its RFP, New Hampshire requested schools to explain how the school's plan will assist at-risk students to meet challenging state content and performance standards. ELLs are one specified type of at-risk students. However, given the fact that New Hampshire's initial six CSRD schools collectively enrolled only 3 of the state's more than 2,000 ELL students, it seems misleading to characterize this reference as proof that the SEA

TABLE 5

Maine

\begin{tabular}{|c|c|c|c|}
\hline Section and Page Number & Description & Peripheral & Concrete \\
\hline $\begin{array}{l}\text { RFP Appendix B- } \\
\text { Supporting Your Model: } \\
\text { A Continuum for } \\
\text { Effectiveness (Green), } \\
\text { p. 3, line } 6 \text { from bottom }\end{array}$ & $\begin{array}{l}\text { Reference to language minority } \\
\text { composition with respect to student } \\
\text { demographics. Mentioned in "Continuum } \\
\text { of Evidence of Effectiveness" chart as part } \\
\text { of implementation item. }\end{array}$ & & \\
\hline $\begin{array}{l}\text { RFP Continuum of } \\
\text { Evidence (Orange), } \\
\text { p. } 10 \text {, line } 7 \text { from bottom }\end{array}$ & $\begin{array}{l}\text { Reference to dominant language. } \\
\text { Mentioned in one of the evaluation } \\
\text { indicators. The indicator entails the } \\
\text { disaggregation, analysis, and interpretation } \\
\text { of student data by a list of factors. } \\
\text { Dominant language is part of this list. }\end{array}$ & & \\
\hline
\end{tabular}

Note. $\quad \mathrm{RFP}=$ Request for Proposals. 
wanted to ensure schools' responsiveness to ELLs. Moreover, the exact match with the language of the Massachusetts application (which was submitted earlier and shared with colleagues in New Hampshire) suggested it was borrowed, not necessarily with deep reflection.

Vermont's two references to ELLs (see Table 7) both came directly from the federal guidelines to states.

TABLE 6

New Hampshire

\begin{tabular}{|c|c|c|c|}
\hline $\begin{array}{l}\text { Section and } \\
\text { Page Number }\end{array}$ & Description & Peripheral & Concrete \\
\hline $\begin{array}{l}\text { State APP, p. } 5 \text {, } \\
\text { line } 7 \text { from bottom }\end{array}$ & $\begin{array}{l}\text { Reference to children who speak English as a } \\
\text { second language as an at-risk population to be } \\
\text { considered in reference to local school } \\
\text { improvement initiatives. These initiatives were } \\
\text { to be compiled in a Resource Guide of promising } \\
\text { practices for New Hampshire educators. }\end{array}$ & & \\
\hline $\begin{array}{l}\text { State APP, p. } 14 \text {, } \\
\text { 5th paragraph }\end{array}$ & $\begin{array}{l}\text { Reference to Limited English Proficient status } \\
\text { as a Title I category by which the } \\
\text { assessment of student performance results } \\
\text { should be disaggregated. }\end{array}$ & & \\
\hline $\begin{array}{l}\text { State RFP, p. } 6 \text {, } \\
\text { line } 3\end{array}$ & $\begin{array}{l}\text { Reference to ELLs as an at-risk population } \\
\text { to be addressed in the school application } \\
\text { section entitled "Description of Proposed } \\
\text { Program's Vision." }\end{array}$ & & \\
\hline $\begin{array}{l}\text { State RFP, } 15 \text { th page, } \\
\text { line } 17\end{array}$ & $\begin{array}{l}\text { Reference to ELLs as part of Item } 4 \text { in the } \\
\text { school application section of scoring rubric. }\end{array}$ & & \\
\hline
\end{tabular}

Note. $\quad \mathrm{APP}=$ Application; ELLs = English Language Learners; RFP = Request for Proposals.

TABLE 7

Vermont

\begin{tabular}{|c|c|c|c|}
\hline $\begin{array}{l}\text { Section and } \\
\text { Page Number }\end{array}$ & Description & Peripheral & Concrete \\
\hline $\begin{array}{l}\text { State APP, p. } 9 \text {, } \\
\text { line } 9 \text { from bottom }\end{array}$ & $\begin{array}{l}\text { Reference to children with limited English } \\
\text { proficiency in Item } 2 \text {, "Comprehensive } \\
\text { design with aligned components," in list of } \\
9 \text { components of CSRD programs. }\end{array}$ & & \\
\hline State RFP, 6th page & $\begin{array}{l}\text { Reference to children with limited English } \\
\text { proficiency in Item } 2 \text {, "Comprehensive } \\
\text { design with aligned components," in list of } \\
9 \text { components of CSRD programs. }\end{array}$ & & \\
\hline
\end{tabular}

Note. $\mathrm{APP}=$ Application RFP $=$ Request for Proposals. 
New York's application (see Table 8) had the fewest references to ELLs-only one, actually, and that one merely promised compliance with Title I requirements for disaggregation of data. As noted earlier, however, we are more optimistic about New York than this single reference would suggest. This is because subsequent SEA actions indicated a clear intent for ELL responsiveness. Notably, New York's CSRD state evaluation, prepared by the University of the State of New York, includes more than a dozen concrete references to ELLs and conveys an overt expectation that schools will act to make ELLs central to their school reform program. That evaluation's "Survey of CSRD Program Implementing Schools" asks ELL-specific questions to measure parent and community involvement (e.g., schools are asked if they have homework hotlines appropriate for ESOL families) and to measure program benchmarks (e.g., schools are asked if supplementary immersion programs have been put into place as part of an academic intervention strategy). Based on this latter evidence, shortly after the initial roll-out of CSRD, New York was actively thinking about this segment of the student population. The ultimate role of the state's evaluation strategy in guiding CSRD there remains uncertain, however. A follow-up study looking specifically at the content and consequences of New York's SEA-level CSR evaluations as they have related to ELLs would be informative.

\section{THE PERSISTENT DICHOTOMY}

The central concern of this report is that what could have happened largely did not. Largely missed by SEAs were opportunities to (a) scrutinize the implications of CSR models for ELLs; (b) urge consideration and adoption of practices that had a proven favorable record with ELLs in dual-language, Title VII, or Migrant Education programs; and (c) ensure that student assessments to measure CSR implementation and consequences were ELL-appropriate. The SEAs did little to bridge the dichotomy noted by Miramontes et al. (1997). This was true in both low ELL-impacted states (e.g., Maine and New Hampshire), where there were few ELLs enrolled in CSRD schools, and in the more impacted jurisdictions (e.g., New York and Connecticut). It was also true of both larger SEAs and smaller ones.

TABLE 8

New York

\begin{tabular}{|c|c|c|c|}
\hline $\begin{array}{l}\text { Section and Page } \\
\text { Number }\end{array}$ & Description & Peripheral & Concrete \\
\hline $\begin{array}{l}\text { State APP, p. } 8 \text {, } \\
\text { line } 8 \text { from bottom }\end{array}$ & $\begin{array}{l}\text { Reference to limited-English-proficient status. } \\
\text { Mentioned as a Title I category by which the } \\
\text { analysis on student progress should be } \\
\text { disaggregated. }\end{array}$ & & \\
\hline
\end{tabular}

Note. $\quad \mathrm{APP}=$ Application 
When CSRD was launched, SEAs were consumers, or at least adjudicators, in the CSRD process. SEAs had the power to accept or deny a school's CSRD application and thus to reject certain models. At the very least, they had the power to reject them if there was no additional information in the application ensuring ELL inclusion despite limitations on that topic in the proposed model. Thus SEAs could have pressured model developers, as well as schools, to be more ELL responsive.

One complicating factor as CSRD was initiated was the dramatically broad range of models suggested as possible for school adoption. Stringfield et al. (1998) noted the diversity among model providers on the model's degree of prescriptiveness. Some models (e.g., Success for All) are highly prescriptive; others (e.g., the Coalition of Essential Schools) specify principles to be observed but otherwise recommend local decision making for figuring out the hows of implementation. The research on ELLs addresses the issue of prescriptiveness. Miramontes et al. (1997) found that in schools that best support linguistically diverse students' academic success, "Staff must be empowered to design a new curriculum, make decisions on the mode of language use, and determine student groupings" (p. 30). Reconciling such research findings is an example of an issue where model providers are interested parties, so SEA guidance could have been useful. None of the state plans we reviewed, however, broached this kind of issue.

Although we do note that some models are adjustable and can serve ELLs (Wilde et al., 1999), we find the apparent exclusion from CSRD of programs originally created for ELLs to be problematic. Why, within CSRD, was it never loudly asked: What can be learned from effective pedagogies with ELLs that can guide schooling of all students? Similarly, knowing that ELL students were a substantial population at many schools that were to be candidates for CSRD, why was there little obvious pressure to encourage such schools to assume that what works for ELLs could be the starting point for how to restructure those schools?

The paucity of ELL references in SEA CSRD plans may have reflected a relative lack of expertise on issues of ELL accommodation on the part of those charged with coordinating CSRD efforts at the state level. If that was the case, then the problem could be straightforwardly diagnosed as state personnel not being well-positioned to sustain and scale up ELL-responsive reforms. With programs for ELLs historically marginal (Grey, 1991; Nieto, 2000), and with past ELL enrollments both lower and less geographically dispersed, it seems probable that many educators who climbed career ladders to positions at SEAs could have done so without much grounding in ELL-related educational issues. Thus SEA-based educators, circa 1998 (and now), may indeed have been missing key information regarding ELL responsiveness.

According to this problem diagnosis, SEAs should move to develop key personnel's expertise on effective strategies for educating ELLs. With that knowledge base in place, SEA staff would be better positioned to scrutinize school plans for ELL responsiveness, to encourage ELL responsiveness by district-level and school personnel, to look skeptically at school plans using models that are not ELL re- 
sponsive, and to be sources of information regarding how to bridge the unnecessary dichotomy between whole-school reform initiatives and the issues of ELL accommodation. Perhaps the challenge could be addressed by having SEA personnel familiarize themselves with the research of Dentler and Hafner (1997), Miramontes et al. (1997), and others. Case histories exist that describe successful bilingual education and other programs from which ELLs have benefited. ${ }^{11}$

The very act of raising the politically controversial topic of bilingual education makes us think that probably the challenge of making the school reform movement (including at the SEA level) more responsive to ELLs is, and was, more complicated than the straightforward acquisition of new knowledge. Why, circa 1998, were many SEA personnel who were making CSRD decisions either not versed on ELL issues or not disposed to see as salient the knowledge on the topic that they did have?

One explanation is bureaucratic. As Lusi (1997) noted, SEAs are not typically learning organizations unless there are conscious intentions and efforts to make them so. Hypothetically, CSRD program implementers could have learned from Title VII Coordinators, Migrant Education Coordinators, and other SEA staff who had expertise in ELL education, but for this to be likely, structures and expectations needed to be in place to encourage such an exchange.

Yet an explanation that starts and ends with "that's just bureaucracy" is inadequate because it is insufficiently concerned with politics and power. SEAs oversee systems that are responsive to many students. Why not ELLs? Or, why not ELLs very often? Acknowledging that the dichotomy between ELL-responsive schooling and CSR has been habitual and longstanding does not make it devoid of political ramifications. Institutional racism need not be explicit or intentional to have serious consequences.

In 1992, before dramatic reforms like the banning of bilingual education under California's Proposition 227, and before the elimination of Title VII with the No Child Left Behind Act, Fillmore and Meyer (1992) noted that for 25 years, viable mechanisms to capture and disseminate ELL-responsive procedural knowledge had been consistently undercut. Perhaps that explains why none of the models and practices implemented with ELLs through Title VII, Migrant Education, and multiple other mechanisms was a source for CSRD models in 1998. (We refer here to externally developed CSRD models, as we can make no claims regarding the origins of the locally developed models used by some schools in their CSRD efforts.) It was as if there was an assumption among SEA staffs (and at multiple other tiers of the formal education enterprise) that nothing broadly applicable could be learned from the effective instruction of ELLs, or that it was tolerable for schools and systems with substantial ELL enrollments to not see it as imperative that their leaders rapidly acquire a thorough understanding regarding ELL-responsive school practice.

Although our tone here is overtly insistent and critical, we do not wish to suggest that all was bleak for ELLs in these states circa 1998. However vague and pe-

\footnotetext{
${ }^{11}$ See Portraits of Success, available at http://www.lab.brown.edu/public/NABE/portraits.taf.
} 
ripheral the seven SEAs' references to ELLs were, there was an underdeveloped acknowledgment in the plans we reviewed that CSR must include ELLs, that school reform needed to include "all students." That foundational condition could be built on, and we saw some evidence (e.g., New York's evaluation plan) that in subsequent years it was.

Nor do we wish to remove ourselves from the described problem or the construction of that problem's solution. As mentioned earlier, our organization formally agreed to assist the seven studied SEAs in their initial CSRD roll-out. In that work, we and our colleagues did not originally see how SEAs were missing a chance to bridge the CSR/ELL-responsiveness dichotomy, although by mid-2000, when we began the research described here, we began to uncover the problem. Since then, our organization has assembled a research synthesis on CSR and ELL-responsiveness (Coady et al., 2003). We also have hired a former TESOL professor as point person for our CSRD involvement and hosted two conferences on this topic in 2003. Although the Miramontes' (1997) dichotomy has complex origins and is persistent, we insist, as she and her co-authors did, that it is not inevitable or unavoidable. We believe that SEAs, our organization, and research groups like ours can and should contribute to bridging the gap between CSR and ELL responsiveness.

\section{ACKNOWLEDGMENTS}

This article is partially based on work completed for the Education Alliance at Brown University and was supported by the Institute of Educational Sciences (IES), U.S. Department of Education, under contracts ED-01-CO-0010 and RJ96005401. The opinions, findings, and conclusions or recommendations expressed in this article are those of the authors and do not necessarily reflect the views of IES, the U.S. Department of Education, any other agency of the U.S. Government, or the Education Alliance. An earlier report entitled "English Language Learners, the Comprehensive School Reform Demonstration Project, and the Role of State Departments of Education" was also drafted by the authors of this article and is available on The Education Alliance's website: http://www.alliance.brown.edu/pubs/csrd/ELLCSRD_rpt.pdf.

\section{REFERENCES}

Beck, S. A. L., \& Allexsaht-Snider, M. (2001). Recent language minority education policy in Georgia: Appropriation, assimilation, and Americanization. In S. Wortham, E. G. Murillo, \& E. T. Hamann (Eds.), Education in the new Latino Diaspora (pp. 37-66). Westport, CT: Ablex.

Beeman, W. (2004). Introduction: Margaret Mead: America's premier analyst. In M. Mead (Ed.), Studying contemporary Western society: Theory and method (pp. x-xix). New York: Berghahn.

Berends, M., Kirby, S. N., Naftel, S., \& McKelvey, C. J. (2001). Implementation and performance in New American Schools: Three years into scale-up. Washington, DC: Rand. 
Berman, P., Aburto, S., Nelson, B., Minicucci, C., \& Burkart, G. (2000). Going schoolwide: Comprehensive school reform inclusive of limited English proficient students, a resource guide (NCBE resource collection series, 17). Washington, DC: George Washington University, Center for the Study of Language and Education.

Berman, P., Minicucci, C., McLaughlin, B., Nelson, B., \& Woodworth, K. (1995). School reform and student diversity: Case studies of exemplary practices for LEP students. Washington, DC: National Clearinghouse for Bilingual Education.

Borman, G. (2002). Title I: The evolution and effectiveness of compensatory education. In S. Stringfield \& D. Land (Eds.), Educating at-risk students: One hundred first Yearbook of the National Society for the Study of Education, Part II (pp. 231-245). Chicago: University of Chicago Press.

Borman, G., Hewes, G., Overman, L., \& Brown, S. (2003). Comprehensive school reform and achievement: A meta-analysis. Review of Educational Research, 73, 125-230.

California State Department of Education. (1981). Schooling and language minority students: A theoretical framework. Los Angeles: Evaluation, Dissemination, and Assessment Center, California State University, Los Angeles.

California State Department of Education. (1986). Beyond language: Social and cultural factors in schooling language minority students. Los Angeles: Evaluation, Dissemination, and Assessment Center, California State University, Los Angeles.

Coady, M., Hamann, E., Harrington, M., Pacheco, M., Pho, S., \&Yedlin, J. (2003). Claiming opportunities: A handbook for improving education for English language learners through comprehensive school reform. Providence, RI: Education Alliance at Brown University.

Connecticut State Board of Education. (1996). Nurturing the genius of Connecticut's schools, Connecticut's comprehensive plan for education 1996-2000. Hartford, CT: Author.

Crawford, J. (1995). Bilingual education: History, politics, theory, and practice (3rd ed.). Los Angeles: Bilingual Education Services.

Cummins, J. (1989). Empowering minority students. Sacramento: California Association for Bilingual Education.

Datnow, A., Borman, G., Stringfield, S., Overman, L., \& Castellano, M. (2003). Comprehensive school reform in culturally and linguistically diverse contexts: Implementation and outcomes from a 4-Year Study. Educational evaluation and policy analysis, 25, 143-170.

Datnow, A., Borman, G., Stringfield, S., Rachuba, L., \& Castellano, M. (2002, April). Comprehensive school reform in culturally and linguistically diverse contexts: Implementation and outcomes from a 4-Year study. Paper presented at the annual meeting of the American Educational Research Association, New Orleans, LA.

Datnow, A., \& Stringfield, S. (2000). Working together for reliable school reform. Journal of Education for Students Placed At Risk, 5, 183-204.

Dentler, R. A., \& Hafner, A. L. (1997). Hosting newcomers: Structuring educational opportunities for immigrant children. New York: Teachers College Press.

Deschenes, S., Cuban, L., \& Tyack, D. (2001). Mismatch: Historical perspectives on schools and students who don't fit them. Teachers College Record, 103, 525-547.

Desimone, L. (2002). How can comprehensive school reform models be successfully implemented? Review of Educational Research, 72, 433-479.

Durán, R. P. (1989). Testing of linguistic minorities. In R. L. Linn (Ed.), Educational measurement (3rd ed.; pp. 573-587). New York: Macmillan.

Fillmore, L. W., \& Meyer, L. M. (1992). The curriculum and linguistic minorities. In P. W. Jackson (Ed.), The handbook of research on curriculum (pp. 626-658). New York: MacMillan.

Fink, D. (2000). Good schools/real schools: Why school reform doesn't last. New York: Teachers College Press.

Gándara, P. (1994). The impact of the educational reform movement on limited English proficient students. In B. McLeod (Ed.), Language and learning: Educating linguistically diverse students (pp. 45-70). Albany: State University of New York Press. 
Garcia, E. E. (1998). Foreword. In M. C. Pugach (Ed.), On the border of opportunity: Education, community, and language at the U.S.-Mexico line (pp. vii-viii). Mahwah, NJ: Lawrence Erlbaum Associates, Inc.

Genesee, F. (Ed.). (1999). Program alternatives for linguistically diverse students. (Educational Practice Report No. 1.). Santa Cruz, CA: Center for Research on Education, Diversity, and Excellence.

Genesee, F., \& Upshur, J. A. (1996). Classroom-based evaluation in second language education. New York: Cambridge University Press.

Gómez, E. L. (1998). Perspectives on policy and practice: Creating large-scale assessment portfolios that include English language learners. Providence, RI: Northeast and Islands Regional Educational Laboratory at Brown University.

Grey, M. A. (1991). The context for marginal secondary ESL programs: Contributing factors and the need for further research. Journal of Educational Issues of Language Minority Students, 9, 75-89.

Griego-Jones, T. (1995). Implementing bilingual programs is everybody's business (NCBE Focus Occasional Papers in Bilingual Education, No. 11.) Washington, DC: National Clearinghouse on Bilingual Education.

Hamann, E. T. (2003). The educational welcome of Latinos in the New South. Westport, CT: Praeger.

Hamann, E. T., Lane, B., \& Hudak, M. (2000). CSRD roll-out in Maine: Lessons from a statewide case study. Providence, RI: Northeast and Islands Regional Educational Laboratory.

Hamann, E. T., \& Lane, B. (2004). The roles of state departments of education as policy intermediaries: Two cases. Educational Policy, 18(3), 426-445.

Hamann, E. T., Zuliani, I., \& Hudak, M. (2001). English language learners, the Comprehensive School Reform Demonstration project, and the role of state departments of education. Providence, RI: Northeast and Islands Regional Educational Laboratory at Brown University.

Hamayan, E. V. (1995). Approaches to alternative assessment. Annual Review of Applied Linguistics, $15,212-226$.

Hamayan, E. V., \& Damico, J., (Eds.). (1991). Limiting bias in the assessment of bilingual students. Austin, TX: Pro-Ed.

Hatch, T. (2000). What does it take to "Go to scale"? Reflections on the promise and perils of comprehensive school reform. Journal of Education for Students Placed At Risk, 5, 339-354.

Kindler, A. (2002). Survey of the states' limited English proficient students and available educational programs and services: 2000-2001 summary report. Washington, DC: National Clearinghouse for English Language Acquisition and Language Instruction Educational Programs.

LaCelle-Peterson, M., \& Rivera, C. (1994). Is it real for all kids? A framework for equitable assessment policies for English language learners. Harvard Educational Review, 64, 55-75.

Lachat, M. A. (1999). What policymakers and school administrators need to know about assessment reform for English language learners. Providence, RI: Northeast and Islands Regional Educational Laboratory at Brown University.

Lachat, M. A., \& Spruce, M. (1998). Assessment reform, equity, and English language learners: An annotated bibliography. Providence, RI: Northeast and Islands Regional Educational Laboratory at Brown University.

Levinson, B., \& Sutton, M. (2001). Introduction: Policy as/in practice-a sociocultural approach to the study of educational policy. In M. Sutton \& B. Levinson (Eds.), Policy as practice: Toward a comparative sociocultural analysis of educational policy (pp. 1-22). Westport, CT: Ablex.

Lucas, T. (1993). Applying elements of effective secondary schooling for language minority students: A tool for reflection and stimulus to change. Washington, DC: National Clearinghouse on Bilingual Education.

Lucas, T. (1997). Into, through, and beyond secondary school: Critical transitions for immigrant youth. McHenry, IL: Delta Systems.

Lucas, T. (2000, December). Addressing the needs of students at risk of academic failure. Panel presentation at a conference entitled Closing the Achievement Gap at the Secondary Level Through Comprehensive School Reform, Atlanta, GA. 
Lucas, T., Henze, R., \& Donato, R. (1990). Promoting the success of Latino language-minority students: An exploratory study of six high schools. Harvard Education Review, 60, 315-340.

Lucas, T., \& Wagner S. (1999). Facilitating secondary English language learners' transition into the mainstream. TESOL Journal, 8(4), 6-13.

Lusi, S. F. (1997). The role of state departments of education in complex school reform. New York: Teachers College Press.

McLeod, B. (1994). Linguistic diversity and academic achievement. In B. McLeod (Ed.), Language and learning: Educating linguistically diverse students (pp. 9-44). Albany: State University of New York Press.

Mead, M., \& Metraux, R. (1953). The study of culture at a distance. Chicago: University of Chicago Press.

Menken, K. (2000). Do the models fit? Towards comprehensive school reform for English language learners. Washington, DC: National Clearinghouse for Bilingual Education, Center for the Study of Language and Education.

Miramontes, O. B., Nadeau, A., \& Commins, N. L. (1997). Restructuring schools for linguistic diversity: Linking decision making to effective programs. New York: Teachers College Press.

Nader, L. (1972). Up the anthropologist-Perspectives gained from studying up. In D. Hymes (Ed.), Reinventing anthropology (pp. 284-311). New York: Pantheon.

Nieto, S. (2000). Bringing bilingual education out of the basement, and other imperatives for teacher education. In Z. Beykont (Ed.), Lifting every voice: Pedagogy and the politics of bilingualism (pp. 187-207). Cambridge, MA: Harvard Education Publishing Group.

Northwest Regional Educational Laboratory, Center for School and District Improvement. (2004). English language learner (ELL) programs at the secondary level in relation to student performance. Portland, OR: Author.

O’Malley, J. M., \& Valdez-Pierce, L. (1996). Authentic assessment for English language learners: Practical approaches for teachers. White Plains, NY: Addison Wesley Longman.

Patton, M. Q. (1990). Qualitative evaluation and research methods. Newbury Park, CA: Sage.

Pugach, M. (1998). On the border of opportunity: Education, community, and language at the U.S.-Mexico line. Mahwah, NJ: Lawrence Erlbaum Associates, Inc.

Quiroz, P.A. (2001). Beyond educational policy: Bilingual teachers and the social construction of teaching "science" for understanding. In M. Sutton \& B. Levinson (Eds.), Policy as practice: Toward a comparative sociocultural analysis of educational policy (pp. 167-192). Westport, CT: Ablex.

Rivera, C., Stansfield, C., Scialdone, L., \& Sharkey, M. (2000). An analysis of state policies for the inclusion and accommodation of English language learners in state assessment programs during 1998-99. Washington, DC: Center for Equity and Excellence in Education, Region III Comprehensive Center.

Romo, H. D., \& Falbo, T. (1996). Latino high school graduation: Defying the odds. Austin: University of Texas Press.

Saville-Troike, M. (1991). Teaching and testing for academic achievement: The role of language development (Focus: Occasional Papers in Bilingual Education, No. 4). Washington, DC: National Clearinghouse for Bilingual Education.

Shore, C., \& Wright, S. (1997). Policy: A new field of anthropology. In C. Shore \& S. Wright (Eds.), Anthropology of policy: Critical perspectives on governance and power (pp. 3-39). London: Routledge.

Simmons, W. (2000, December). Untitled keynote address presented at a conference entitled Closing the Achievement Gap at the Secondary Level Through Comprehensive School Reform, Atlanta, GA.

Sizer, T. R. (1984). Horace's compromise: The dilemma of the American high school. Boston, MA: Houghton Mifflin Company.

Solano-Flores, G., \& Trumbull,E. (2003). Examining language in context: The need for new research and practice paradigms in the testing of English-language learners. Educational Researcher, 32(2), 3-13.

Stringfield, S., Datnow A., Ross, S. M., \& Snively, F. (1998). Scaling up school restructuring in multicultural, multilingual contexts: Early observations from Sunland County. Education and Urban Society, 30, 326-357. 
Suárez-Orozco, C., \& Suárez-Orozco, M. (2001). Children of immigration. Cambridge, MA: Harvard University Press.

U.S. General Accounting Office. (2001). Meeting the needs of students with limited English proficiency (GAO-01-226). Washington, DC: Author.

Valdés, G. (2001). Learning and not learning English: Latino students in American schools. New York: Teachers College Press.

Valdez, C. M. (1989). Language minority students and educational reform: An incomplete agenda. In S. Cohen \& L. Solomon (Eds.), From the campus: Perspectives on the school reform movement (pp. 154-169). New York: Praeger.

Valenzuela, A. (1999). Subtractive schooling: U.S.-Mexican youth and the politics of caring. Albany: State University of New York Press.

Walquí, A. (2000). Access and engagement: Program design and instructional approaches for immigrant students in secondary school. McHenry, IL: Delta Systems.

Wilde, J., Thompson, B., \& Herrera, R. M. (1999). Guide: Comprehensive school reform models addressing the needs of English language learners. Rio Rancho, NM: Southwest Comprehensive Center Region IX.

Wortham, S. (2001). Gender and school success in the Latino Diaspora. In S. Wortham, E. G. Murillo, \& E. T. Hamann (Eds.), Education in the new Latino Diaspora (pp. 117-141). Westport, CT: Ablex.

Wortham, S., Murillo, E. G., \& Hamann, E. T. (Eds.). (2001). Education in the new Latino Diaspora: Policy and the politics of identity. Westport, CT: Ablex.

Yonezawa, S., \& Datnow, A. (1999). Supporting multiple reform designs in a culturally and linguistically diverse school district. Journal of Education for Students Placed At Risk, 4, 101-125.

Zehler, A., Fleischman, H., Hopstock, P., Stephenson, T., Pendzick, M., \& Sapru, S. (2003). Descriptive study of services to LEP students and LEP students with disabilities, Volume I: Research report. Development Associates, Inc. Retrieved May 12, 2004, from http://www.devassoc1.com/LEP.htm

Zehr, M. A. (2000, November 22). Ed. dept. warns states to comply with Title I rules. Education Week, 20 , p. 23. 